\title{
Role of shear wave elastography in characterization of hepatic focal lesions
}

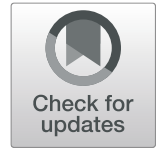

Dena M. Serag ${ }^{1}$, Eman A. Ebeid ${ }^{2 *}$, Basma A. Dessouky ${ }^{1}$ and Hazem Omar ${ }^{3}$

\begin{abstract}
Background: Elastography is a recently developed diagnostic method that aims to evaluate tissue stiffness. Its utility is based on the fact that pathological tissues are generally stiffer than surrounding healthy tissues which often show up as a hard lesion. Shear wave elastography (SWE) is a new technique based on shear waves that has been implemented in diagnostic ultrasound (US) systems. The aim of this study is to study the role of shear wave elastography in differentiation between benign and malignant hepatic focal lesions.

Results: The study was conducted on 110 patients (92 males, 18 females) with a mean age of 51.7 years. Age range was from 30 to 70 years; 28 patients were diagnosed with benign lesions, and 82 with malignant lesions. SWE shows that there is a significant difference in stiffness between malignant and benign lesions with $p$ value $=$ 0.002 and with mean \pm SD of $10.3 \pm 6.31 \mathrm{kPa}$ for the benign lesions and $16.2 \pm 9.32 \mathrm{kPa}$ for the malignant group. A cutoff value of 13.24 was selected to differentiate between benign and malignant lesions using the SWE mean providing sensitivity $78.04 \%$, specificity $71.42 \%$, and accuracy $64.2 \%$.

Conclusion: SWE is a good tool in the differentiation of benign and malignant hepatic focal lesions.

Keywords: Shear wave elastography, Elastography, SWE, Hepatic focal lesions
\end{abstract}

\section{Background}

Liver tumors are tumors or growths on or in the liver. Several distinct types of tumors can develop in the liver because the liver is made up of various cell types. These growths can be benign or malignant. They may be discovered on medical imaging (even for a different reason than the cancer itself) or may be present in patients as an abdominal mass, hepatomegaly, abdominal pain, jaundice, or some other liver dysfunction [1]. Because of its advantageous cost/benefit ratio, widespread availability, and easy execution, ultrasound (US) is the first-line imaging modality in most countries for the initial liver survey and represents the imaging technique that usually detects complex liver lesions [2]. It is generally agreed that no other physical parameter of tissue is changed by pathological or physiological process to a remarkable extent as the tissue elasticity [3]. SWE estimates the speed

\footnotetext{
* Correspondence: monna.22222@gmail.com

${ }^{2}$ Department of Radiodiagnosis, Birket Elsaba Hospital, Menoufia, Egypt

Full list of author information is available at the end of the article
}

of shear waves to provide a quantitative estimate of tissue stiffness [4]. SWE has the advantage of being able to image liver tissue stiffness in real time because the shear waves are generated by US impulses [5]. Several features can be described with this technique, including the quantitative evaluation of the lesion elasticity in kilopascals or meters/second and the spatial heterogeneity of stiffness, and moreover, SWE imaging is guided using Bmode images with a higher frame rate. This method can provide more accurate assessment of liver tissue stiffness due to the advantages of SWE and B-mode image guidance $[6,7]$.

The purpose of this study was to evaluate the role of SWE in characterization of hepatic focal lesions.

\section{Methods}

This was a prospective study conducted from December 2017 to March 2019 after the approval of protocol from faculty of medicine ethical committee for human research; fully informed written consent was taken from 
Table 1 Age and sex distribution among the studied patients

\begin{tabular}{|c|c|c|c|c|}
\hline \multirow[t]{2}{*}{ Age } & \multicolumn{2}{|l|}{ Benign (28) (25.5\%) } & \multicolumn{2}{|c|}{ Malignant (82) (74.5\%) } \\
\hline & Male (18) (16.4\%) & Female (10) (9.1\%) & Male (74) (67.3\%) & Female (8) (7.3\%) \\
\hline 30 to $>40$ years (17) (15.5\%) & $4(3.6 \%)$ & $5(5.5 \%)$ & $6(5.5 \%)$ & $2(1.8 \%)$ \\
\hline 40 to $>50$ years $(33)(30 \%)$ & $4(3.6 \%)$ & $3(2.7 \%)$ & $22(20 \%)$ & $4(3.6 \%)$ \\
\hline 50 to $>60$ years (36) $(32.7 \%)$ & $6(5.5 \%)$ & $1(0.9 \%)$ & $28(25.5 \%)$ & $1(0.9 \%)$ \\
\hline 60 to $>70$ years (24) (21.8\%) & $4(3.6 \%)$ & $1(0.9 \%)$ & 18 (16.4\%) & 1 (0.9\%) \\
\hline
\end{tabular}

each patient after given an explanation of the procedures and the importance of the study; the confidentiality of the patient's data was guaranteed, and the patients had the right to refuse participation in this study without giving any reason.

The study enrolled 110 patients: 92 male and 18 females with a mean age 51.7 years after fulfillment of inclusion and exclusion criteria. Inclusion criteria were patient presented with at least one hepatic focal lesion greater than 1 $\mathrm{cm}$ in diameter and not more than $5 \mathrm{~cm}$ deep from the capsule. Exclusion criteria were focal lesion previously managed by intervention radiology, patient with perihepatic ascites, and uncooperative patients.

The patients were subjected to full history taking and laboratory investigations. Real-time ultrasound and shear wave elastogaphy (SWE) was performed using Philips iU22 $\times$ MATRIX ultrasound system with a curved array transducer 3-5 MH. The patients were examined in the supine or left lateral position with right arm elevated above the head to improve intercostal access. Gray scale abdominopelvic ultrasonography was initially performed to evaluate the liver size, echogenicity, texture, outline, and focal lesions. We identified hepatic focal lesions for number, site, size, margin, and echogenicity. Then, in SWE scanning, the patient was instructed to hold his or her breath for a few seconds. We located the segment of hepatic focal lesion, and a region of interest (ROI) was adjusted upon the targeted focal lesion; we took from 5 to 8 measurements for quantitative evaluation of stiffness. Then, the machine estimated the velocity of the propagated shear wave in the ROI and automatically

Table 2 The clinical presentation of the patients

\begin{tabular}{lll}
\hline Clinical presentation & No. & Percentage \\
\hline Abdominal pain & 40 & 36.4 \\
Abdominal distention & 45 & 40.9 \\
Fever & 3 & 2.7 \\
Jaundice & 10 & 9.1 \\
Loss of appetite & 15 & 13.6 \\
Loss of weight & 13 & 11.8 \\
Asymptomatic (accidentally discovered) & 17 & 15.5 \\
Total & 143 & 130 \\
\hline
\end{tabular}

translates it to stiffness in kilopascals (KPs). In patient with more than one focal lesion, we ensured that all lesions have the same pathology guided by other modalities like CT and MRI, and then, we analyzed the most accessible one. Multiple successful measurements are obtained, and the results appear in the final report as the average of all measurements. Then, the data obtained by SWE scanning is compared with the results of triphasic CT and raised tumor markers in 92 patients (84\%), dynamic MRI in 15 patients (13\%), and 3 patients by histopathology to estimate the accuracy, sensitivity, and specificity of SWE in characterization of different hepatic focal lesions.

\section{Statistical analysis}

Data were collected, tabulated, and statistically analyzed using a personal computer with Statistical Package of Social Science (SPSS) version 20 [SPSS Inc., Chicago, IL, USA], where the two types of statistics were done.

\section{Descriptive statistics}

Quantitative data was expressed as mean \pm standard deviation (SD). Qualitative data was expressed as frequency and percentage.

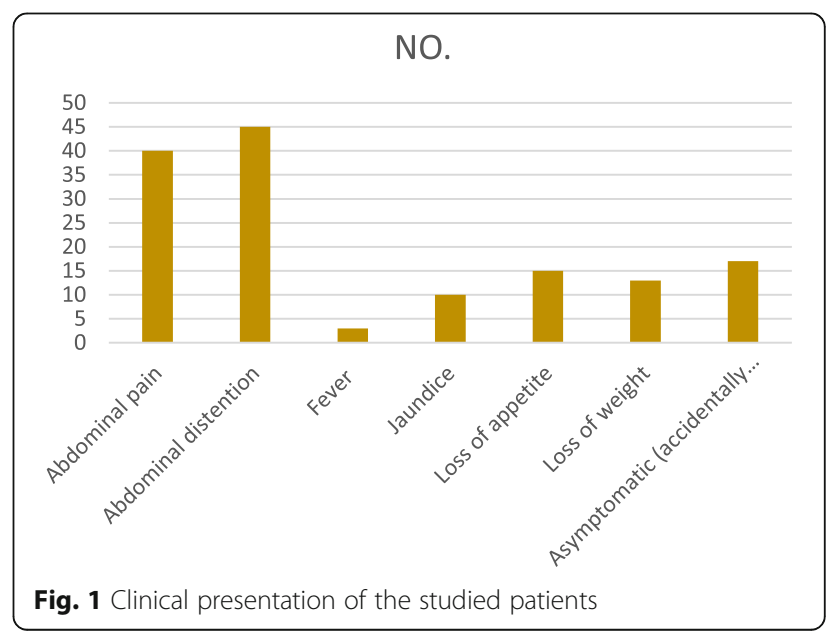


Table 3 Laboratory findings of the studied patients

\begin{tabular}{|c|c|c|c|c|c|}
\hline \multicolumn{2}{|c|}{ Lab investigations } & \multirow{2}{*}{$\begin{array}{l}\text { Benign lesions, } N= \\
28(25.45 \%) \\
4.7 \pm 0.23\end{array}$} & \multirow{2}{*}{$\begin{array}{l}\text { Malignant lesions, } N \\
=82(74.54 \%)\end{array}$} & \multirow{2}{*}{$\frac{x^{2}}{0.751}$} & \multirow{2}{*}{$\begin{array}{l}P \\
\text { value } \\
0.420\end{array}$} \\
\hline $\mathrm{CBC}$ & $\begin{array}{l}\text { RBCS (mean } \pm \\
\text { SD) }\end{array}$ & & & & \\
\hline & $\begin{array}{l}\text { WBCS (mean } \pm \\
\text { SD) }\end{array}$ & $5876.2 \pm 911.2$ & $5395.1 \pm 1037.1$ & 1.56 & 0.120 \\
\hline & $\begin{array}{l}\text { Platelets (mean } \\
\pm \text { SD) }\end{array}$ & $250.3 \pm 39.4$ & $198.2 \pm 67.23$ & 2.745 & 0.009 \\
\hline \multirow[t]{3}{*}{ Virology } & Negative & $10(71.4 \%)$ & $2(4.9 \%)$ & 27.65 & 0.001 \\
\hline & Hepatitis B & $1(7.1 \%)$ & $11(26.8 \%)$ & & \\
\hline & Hepatitis C & $3(21.4 \%)$ & $28(68.3 \%)$ & & \\
\hline \multirow[t]{4}{*}{$\begin{array}{l}\text { Liver } \\
\text { functions }\end{array}$} & $\begin{array}{l}\text { Bilirubin (mean } \\
\pm \mathrm{SD} \text { ) }\end{array}$ & $1.23 \pm 1.67$ & $2.06 \pm 3.6$ & 0.751 & 0.411 \\
\hline & $\begin{array}{l}\text { Albumin } \\
(\text { mean } \pm \text { SD })\end{array}$ & $3.9 \pm 0.2$ & $3.52 \pm 0.54$ & 2.641 & 0.013 \\
\hline & $\begin{array}{l}\text { SGOT (mean } \pm \\
\text { SD) }\end{array}$ & $38.32 \pm 12.35$ & $57.32 \pm 23.10$ & 2.832 & 0.006 \\
\hline & $\begin{array}{l}\text { SGPT (mean } \pm \\
\text { SD) }\end{array}$ & $39.1 \pm 14.20$ & $56.32 \pm 16.14$ & 3.214 & 0.002 \\
\hline \multirow[t]{2}{*}{$\begin{array}{l}\text { Renal } \\
\text { functions }\end{array}$} & $\begin{array}{l}\text { Creatinine } \\
\text { (mean } \pm \text { SD) }\end{array}$ & $3.9 \pm 1.20$ & $1.2 \pm 0.21$ & 1.652 & 0.095 \\
\hline & $\begin{array}{l}\text { Urea (mean } \pm \\
\text { SD) }\end{array}$ & $32.1 \pm 6.25$ & $37.2 \pm 5.64$ & 2.741 & 0.008 \\
\hline INR & $($ mean $\pm S D)$ & $0.91 \pm 0.07$ & $0.97 \pm 0.17$ & 0.851 & 0.376 \\
\hline PC & $($ mean \pm SD) & $75.2 \pm 5.12$ & $72.4 \pm 8.32$ & 0.941 & 0.351 \\
\hline $\begin{array}{l}\text { Tumor } \\
\text { markers }\end{array}$ & $\begin{array}{l}\text { AFP (mean } \pm \\
\text { SD) }\end{array}$ & $22.1 \pm 14.32$ & $504.32 \pm 387.1$ & 4.651 & 0.001 \\
\hline
\end{tabular}

Table 4 Ultrasound criteria in the benign and malignant lesions

\begin{tabular}{|c|c|c|c|c|c|}
\hline \multicolumn{2}{|c|}{ US criteria } & \multirow[t]{2}{*}{$\begin{array}{l}\text { Benign lesions, } N= \\
28(25.45 \%)\end{array}$} & \multirow[t]{2}{*}{$\begin{array}{l}\text { Malignant lesions, } N= \\
82(74.54 \%)\end{array}$} & \multirow{2}{*}{$\frac{x^{2}}{0.895}$} & \multirow{2}{*}{$\begin{array}{l}P \\
\text { value } \\
0.596\end{array}$} \\
\hline Liver & Size & & & & \\
\hline & $\begin{array}{l}\text { - Average } \\
\text { - Enlarged }\end{array}$ & $\begin{array}{l}12(42.9 \%) \\
16(57.1)\end{array}$ & $\begin{array}{l}36(43.9 \%) \\
46(56.1 \%)\end{array}$ & & \\
\hline & Echo pattern & & & 8.564 & 0.004 \\
\hline & $\begin{array}{l}\text { • Non- } \\
\text { cirrhotic } \\
\text { • Cirrhotic }\end{array}$ & $\begin{array}{l}22(78.6 \%) \\
6(21.4 \%)\end{array}$ & $\begin{array}{l}28(34.1 \%) \\
54(65.9 \%)\end{array}$ & & \\
\hline \multirow{6}{*}{$\begin{array}{l}\text { Focal } \\
\text { lesion }\end{array}$} & Number & & & 1.657 & 0.643 \\
\hline & $\begin{array}{l}\text { - One } \\
\text { - Two } \\
\text { - Three } \\
\text { - Multiple }\end{array}$ & $\begin{array}{l}18(64.3 \%) \\
6(21.4 \%) \\
2(7.1 \%) \\
2(7.1 \%)\end{array}$ & $\begin{array}{l}64(78 \%) \\
14(17.1 \%) \\
2(2.4 \%) \\
2(2.4 \%)\end{array}$ & & \\
\hline & Echogenicity & & & 2.854 & 0.410 \\
\hline & $\begin{array}{l}\cdot \\
\text { Echogenic } \\
\dot{\cdot} \\
\text { Heterogenic } \\
\dot{\cdot} \\
\text { Hypoecchoic } \\
\dot{\cdot} \\
\text { Isoecchoic }\end{array}$ & $\begin{array}{l}10(35.7 \%) \\
2(7.1 \%) \\
14(50 \%) \\
2(7.1 \%)\end{array}$ & $\begin{array}{l}1417.1 \%) \\
16(19.5 \%) \\
42(51.2 \%) \\
10(12.2 \%)\end{array}$ & & \\
\hline & Margin & & & 0.323 & 0.124 \\
\hline & $\begin{array}{l}\text { - III-defined } \\
\text { - Well- } \\
\text { defined }\end{array}$ & $\begin{array}{l}6(21.4 \%) \\
22(78.6 \%)\end{array}$ & $\begin{array}{l}24(29.3 \%) \\
58(70.7 \%)\end{array}$ & & \\
\hline Spleen & $\begin{array}{l}\text { - Normal } \\
\text { - Enlarged }\end{array}$ & $\begin{array}{l}18(64.3 \%) \\
10(35.7 \%)\end{array}$ & $\begin{array}{l}24(29.3 \%) \\
58(70.7 \%)\end{array}$ & 5.362 & 0.023 \\
\hline Ascite & • No & $\begin{array}{l}28(100 \%) \\
0(0)\end{array}$ & $\begin{array}{l}46(56.1 \%) \\
36(43.9 \%)\end{array}$ & 9.824 & 0.019 \\
\hline
\end{tabular}

Table 5 Pathological diagnosis among the studied patients

\begin{tabular}{ll}
\hline Benign lesions (28) & Malignant lesions (82) \\
\hline Hemangioma (24) (21.8\%) & HCC (70) (63.6\%) \\
Focal fatty infiltration (4) (3.36\%) & Cholangiocarcinoma (6) (5.4\%) \\
& Metastasis (6) (5.4\%)
\end{tabular}

\section{Analytic statistics}

Independent samples $t$ test of significance will be used when comparing between two means. Chi-square $\left(\chi^{2}\right)$ test of significance will be used in order to compare proportions between two qualitative parameters. ROC curve is a graph called a receiver operating characteristic curve; it is a plot of the true positive rate against the false positive rate for different possible cutoffs of diagnostic test or marker. $p$ value $\leq 0.05$ was considered to be statistically significant. $p$ value $\leq 0.001$ was considered to be highly statistically significant.

\section{Results}

Our study was conducted on 110 patients (92 male (83\%), 18 female (17\%)). The patients' age ranged from 30 to 70 years with a mean age of 50.2 years for the benign lesions and 54.2 years for the malignant; Table 1 shows that the malignant lesions presented more among the male patients aged 50 to 60 years representing $25.5 \%$. Clinical analysis of the clinical presentation of the studied patients revealed that 45 patients (40.9\%) were presented by abdominal distention and 40 patients (36.4\%) were presented by abdominal pain followed by loss of appetite $(13.6 \%)$, loss of weight $(11.8 \%)$, and jaundice (10\%) (Table 2; Fig. 1).

The laboratory findings of the studied patients are summarized in (Table 3); the most significant lab investigations in patients with malignant lesions were alphafeto proteins, hepatitis viral markers, and liver function tests (SGPT, SGOT, albumin) with $p$ value of 0.001 , $0.001,0.002,0.006$, and 0.013 , respectively. Highresolution ultrasound scanning of the 110 patients yielded the detection of 152 focal lesions. In patient with more than one focal lesion, we ensured that all lesions have the same imaging criteria by other modalities like CT and MRI, and then, we analyzed the most accessible

Table 6 SWE stiffness values in the studied patients with benign and malignant lesions

\begin{tabular}{lllll}
\hline SWE criteria & $\begin{array}{l}\text { Benign } \\
\text { lesions }\end{array}$ & $\begin{array}{l}\text { Malignant } \\
\text { lesions }\end{array}$ & t test & $p$ value \\
\hline $\begin{array}{l}\text { SWE mean } \\
\text { (mean } \pm \text { SD) }\end{array}$ & $10.3 \pm 6.31$ & $16.2 \pm 9.23$ & 2.653 & 0.012 \\
$\begin{array}{l}\text { SWE standard } \\
\text { (mean } \pm \text { SD) }\end{array}$ & $4.10 \pm 2.35$ & $6.2 \pm 4.3$ & 2.130 & 0.033 \\
$\begin{array}{l}\text { SWE median } \\
\text { (mean } \pm \text { SD) }\end{array}$ & $10.32 \pm 6.74$ & $17.23 \pm 8.25$ & 3.320 & 0.002 \\
\hline
\end{tabular}


one. Ultrasound imaging criteria for the liver parenchyma and hepatic focal lesions are listed in Table 4. The cirrhotic liver was significantly related to the presence of malignant lesions with $p$ value $<0.004$, while the size of the liver had no statistically significant relationship to the pathology of the lesions with $p$ value 0.6. Also, the presence of splenomegaly and ascites was significantly related to malignancy with $p$ value $<0.02$ and 0.019 , respectively.

Out of the studied 110 patients, 82 patients (74.5\%) were finally diagnosed with malignant lesions (70 of them (63.6\%) had HCC, 6 patients $(5.4 \%)$ with cholangiocarcinoma, 6 patients (5.4\%) with metastasis) and 28 patients $(25.5 \%)$ were finally diagnosed with benign lesions (hemangioma in 24 patients $(21.8 \%)$ and focal fatty infiltration in 4 patients (3.36\%)) as seen in Table 5.

All patients were subjected to shear wave elastography scanning. It showed that there was a significant difference in stiffness ( $p$ value $<0.002$ ) between malignant and benign lesions with mean \pm SD of $10.3 \pm 6.31 \mathrm{kPa}$ for the benign lesions and $16.2 \pm 9.23 \mathrm{kPa}$ for the malignant group as listed in Table 6. Table 7 and Fig. 2 showed that a cutoff point of 13.24 was selected to differentiate between benign and malignant lesions using the SWE mean providing sensitivity $78.04 \%$, specificity $71.42 \%$, positive predictive value $88.8 \%$, negative predictive value $52.6 \%$, and accuracy $64.2 \%$. We found that the 4 focal fatty infiltration were found to have stiffness
Table 7 Validity test of SWE mean regarding benign and malignant lesions

\begin{tabular}{llllllll}
\hline AUC & $p$ value & $\begin{array}{c}\text { Cutoff } \\
\text { point }\end{array}$ & Sensitivity & Specificity & PPV & NPV & Accuracy \\
\hline 0.777 & 0.002 & 13.24 & $78.04 \%$ & $71.42 \%$ & $88.8 \%$ & $52.6 \%$ & $64.2 \%$ \\
\hline
\end{tabular}

mean $\pm \mathrm{SD}$ values of $12.6 \pm 8.8 \mathrm{kPa}$. The 24 hemangioma lesions were found to have stiffness mean \pm SD of $9.5 \pm 4.2 \mathrm{kPa}$ (Fig. 3). The stiffness mean \pm SD of the $70 \mathrm{HCCs}$ was $15.4 \pm 7.2 \mathrm{kPa}$, while the stiffness mean $\pm \mathrm{SD}$ of the 6 cholangiocarcinoma was $32.5 \pm 8.25 \mathrm{kPa}$. The stiffness of the 6 metastatic lesion mean \pm SD was $22.1 \pm 0.4 \mathrm{kPa}$ as described in Table 8 .

\section{Discussion}

The accurate characterization and the differential diagnosis between the different types of FLLs are important aims that all the imaging modalities available today should satisfy [8]. The aim of this study was to assess the accuracy and sensitivity of SWE in characterization of hepatic focal lesions. Shear wave elastography quantitative assessment of focal liver lesions stiffness was done and compared with the final diagnoses obtained by triphasic CT, dynamic MRI, and pathological results. In this work, we found that there was a significant difference in stiffness between benign and malignant groups

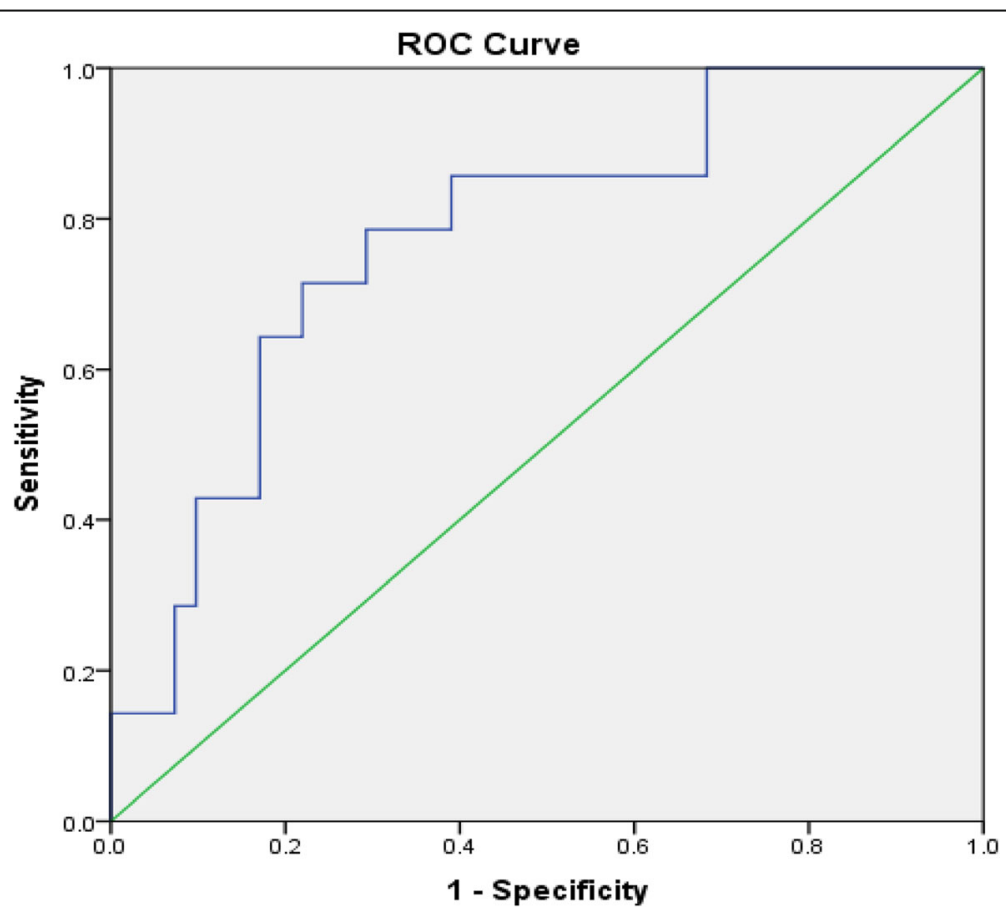

Fig. 2 ROC (receiver operating characteristic) curve of SWE median regarding benign and malignant lesions 


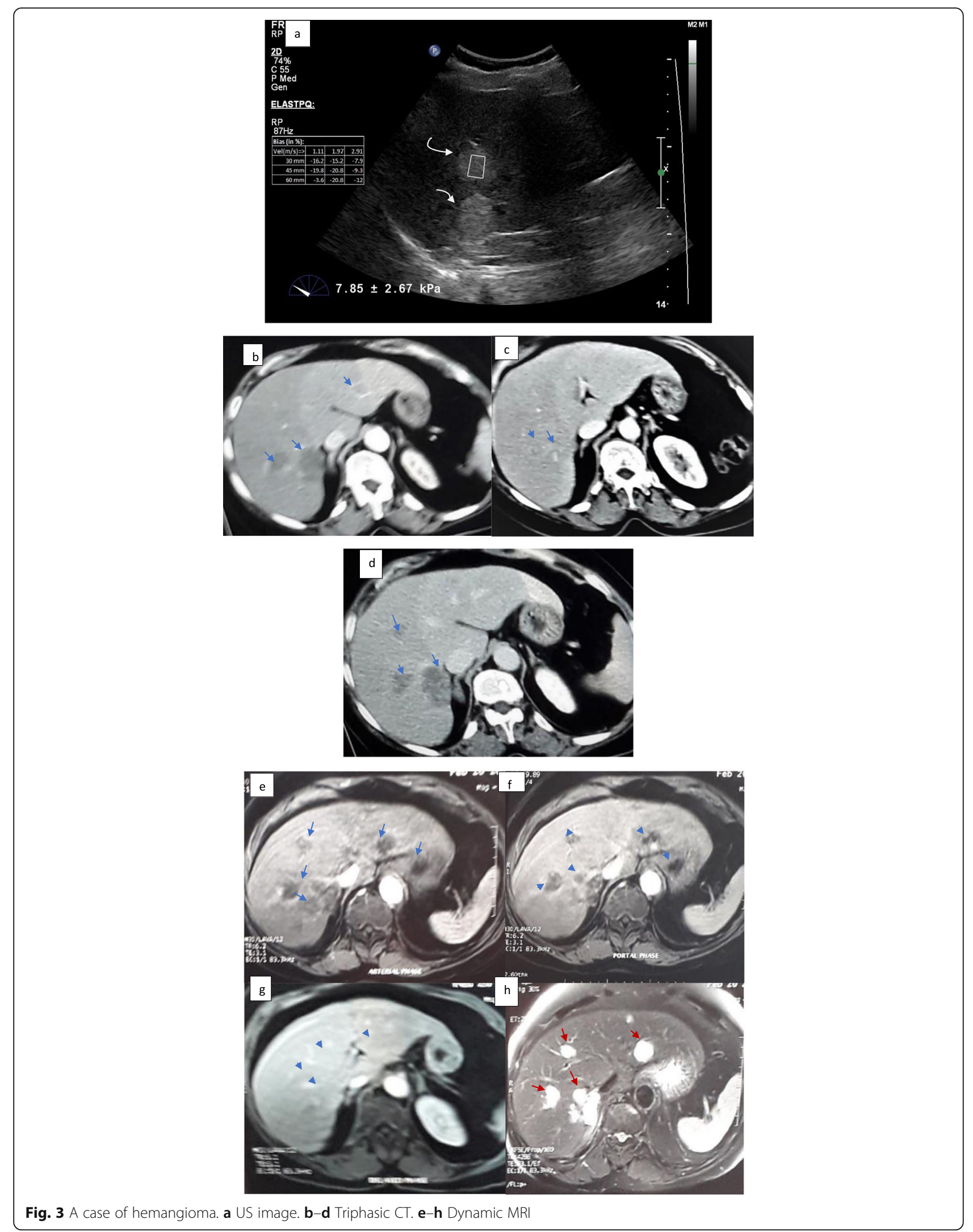


Table 8 Comparison between different types of benign and malignant lesions regarding SWE parameters

\begin{tabular}{lllll}
\hline Lesions & \multicolumn{5}{l}{ SWE parameter } & & \\
\cline { 2 - 5 } & $N=110$ & SWE average (mean \pm SD) & SWE standard (mean \pm SD) & SWE median (mean \pm SD) \\
\hline Hemangioma & $24(21.8 \%)$ & $9.5 \pm 4.2$ & $4.2 \pm 2.3$ & $9.32 \pm 5.37$ \\
Focal fatty infiltration & $4(3.63 \%)$ & $11.2 \pm 5.8$ & $10.1 \pm 6.8$ & $12.4 \pm 7.23$ \\
HCC & $70(63.63 \%)$ & $15.4 \pm 7.2$ & $6.3 \pm 4.6$ & $16.30 \pm 7.54$ \\
Cholangiocarcinoma & $6(5.45 \%)$ & $32.5 \pm 8.25$ & $9.3 \pm 3.2$ & $22.23 \pm 9.4$ \\
Metastasis & $6(5.45 \%)$ & $22.1 \pm 0.4$ & $6.3 \pm 1.02$ & $23.6 \pm 2.64$ \\
\hline
\end{tabular}

with a mean value of $10.32 \pm 6.74$ for benign lesions and $17.23 \pm 8.25$ for malignant lesions with a statistically significant difference of $p<0.002$. This was consistent with Guibal et al. [8] who reported that there was a significant difference in the stiffness between benign and malignant lesions with means of $18.53 \pm 13.5 \mathrm{kPa}$ and 26.9 $\pm 18.8 \mathrm{kPa}$ for benign and malignant lesions, respectively (with high significant difference $p>0.01$ ). Also, Park et al. [9] reported that the stiffness values of malignant lesions were significantly higher than those of benign lesions $(p<0.0001)$, while other studies have not demonstrated any differences (Ronot et al. [10], Frulio et al. [11], Gallotti et al. [12], and Heide et al. [13]).

In this current study, we had 24 cases of hemangiomas which were found to have a mean stiffness of $9.5 \pm 4.2$ $\mathrm{kPa}$. This was close to the results reported by Guibal et al. [8] who reported a mean stiffness of $13.8 \pm 5.5 \mathrm{kPa}$ for the 22 hemangiomas. Guibal et al. explained this elevation in stiffness due to the presence of fibrous septa separating the blood-filled spaces. Ronot et al., Heide et al., Cho et al., and Davies and Koenen [10, 13-15] also described similar observations. In our study, we have 4 focal fatty infiltrations (FFI) which were found to have a mean stiffness of $10.2 \pm 5.8 \mathrm{kPa}$. These results were higher than the values reported by Virchenko et al. [16]. They studied the stiffness values of diffuse hepatic steatosis in 130 patients and reported a mean SWE value of $8.4 \mathrm{kPa}$ for severe steatosis. The difference may be attributed to larger sample size in their study. Ronot et al. [10] also reported similar results regarding diffuse hepatic steatosis with a mean SWE value of $9.6 \pm 4.7 \mathrm{kPa}$.

In the current study, the mean stiffness for 70 hepatocellular carcinomas (HCCs) was $15.4 \pm 7.2 \mathrm{kPa}$. These results are matching with a study carried out by Guibal et al. [8]. They reported a mean stiffness of $14.86 \pm 10$ $\mathrm{kPa}$ for 26 hepatocellular carcinoma which is similar to our study (Fig. 4). Also, our finding was close to those reported by Ronot et al. [10] who reported a mean stiffness value of $19.6 \mathrm{kPa}$. We also found that cholangiocarcinoma and metastasis were the stiffest of all lesion types. SWE value was $32.5 \pm 8.25 \mathrm{kPa}$ for the 6 cholangiocarcinoma. This result was close to Ronot et al. [10] who reported $34.1 \pm 7.3 \mathrm{kPa}$ for the two cholangiocarcinoma.

Our result was lower than that reported by Guibal et al. [8] who reported that cholangiocarcinoma were the stiffest of all lesion types with a mean stiffness value of $56.9 \pm 25.6 \mathrm{kPa}$. The difference in both observations may be due to the small sample size in our study. Guibal et al. [8] explained the elevation of the stiffness value of cholangiocarcinoma to their significant fibrotic component. Also, Masuzaki et al. [17] and Heide et al. [13] reported similar observations about the stiffness value. Also, in this current study, a mean stiffness value of 22.1 $\pm 0.4 \mathrm{kPa}$ was reported for the 6 metastasis cases. This was consistent with Guibal et al. [8]; they studied 53 metastases with mean elasticity values of $21.8 \pm 14.6$. Guibal et al. [8] reported that the elevation in elasticity values found with SWE likely originates from several factors, including changes in vascular and lymphatic permeability, along with changes in collagen deposition and cellular architecture. Malignant lesions grow in an environment restrained by the surrounding tissue, and this can result in an increase in interstitial pressure [8].

There are several limitations encountered with the use of SWE:

1. The primary cause of failure was the lesion location beyond the penetration limits of SWE generally $(>5$ $\mathrm{cm}$ ), major steatosis, and the proximity to vessels.

2. Other failures were attributed to poor intercostal windows and patient inability to hold their breath long enough to acquire a stable SWE acquisition.

3. Another limitation is that the radiologist who acquired the elastography images was not blinded for the diagnosis, and this could introduce bias.

\section{Conclusion}

SWE is a good tool for differentiating between different benign and malignant hepatic focal lesions with high sensitivity, specificity, and accuracy. It shows that there is a significant difference in stiffness between malignant and benign lesions. 


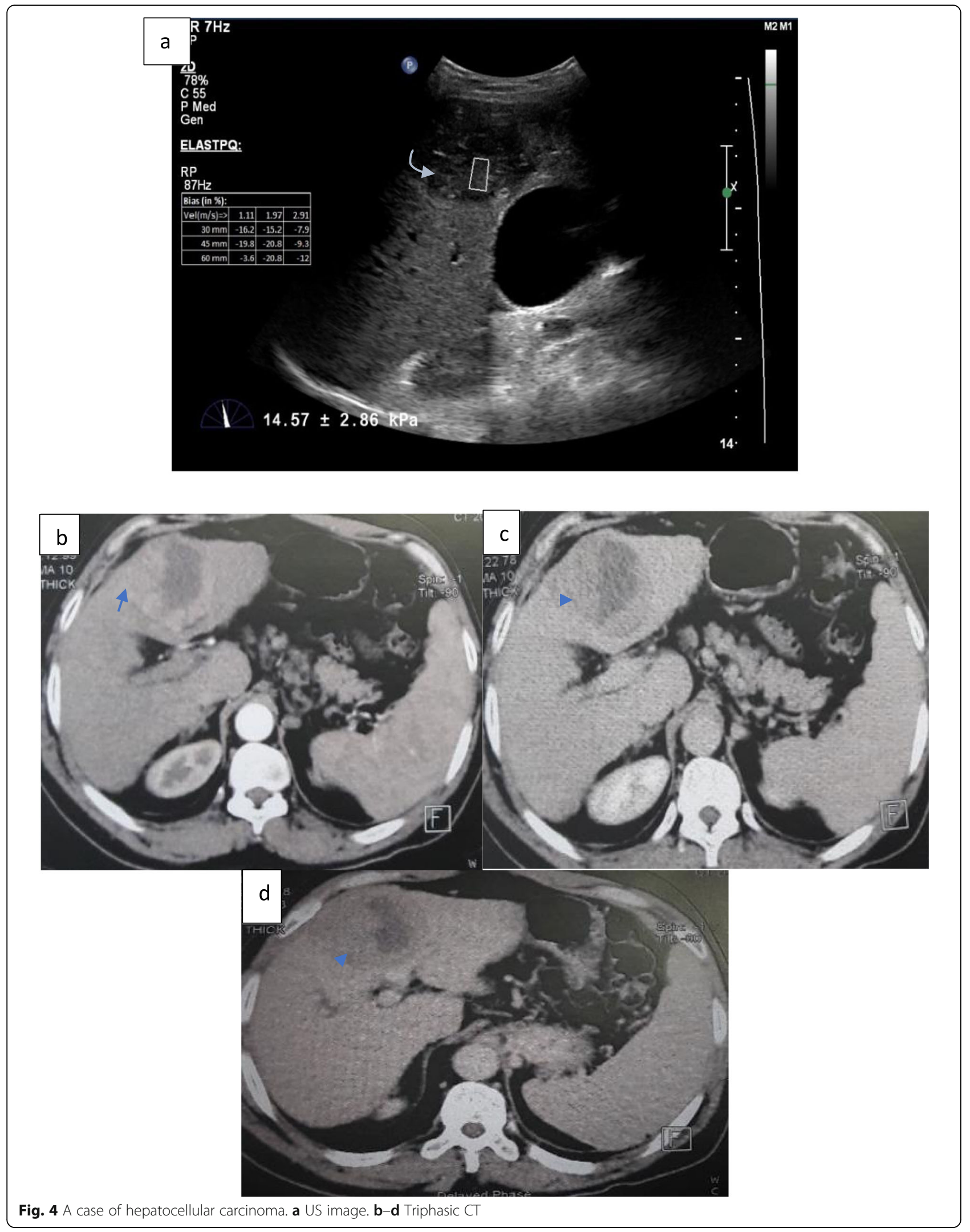




\section{Abbreviations}

SWE: Shear wave elastography; US: Ultrasound; SD: Standard deviation; MH: Megahertz; ROI: Region of interest; kps: Kilopascals; CT: Computed tomography; MRI: Magnetic resonance imaging; FLLs: Focal liver lesions; HCC: Hepatocellular carcinoma; FFI: Focal fatty infiltration

\section{Acknowledgements}

There is no acknowledgement

\section{Authors' contributions}

$\mathrm{DS}, \mathrm{EA}, \mathrm{BD}$, and $\mathrm{HO}$ contributed equally to the study design, data collection, analysis, and interpretation of results. All authors have read and approved the manuscript.

\section{Funding}

There is no funding.

\section{Availability of data and materials}

Data will be available upon request via contacting the corresponding author

\section{Ethics approval and consent to participate}

This study was approved by the Research Ethics Committee of the Faculty of Medicine at Menoufia University in Egypt on 13 March 2016; reference number of approval: 32016-RAD. All patients included in this study gave written informed consent to participate in this research.

\section{Consent for publication}

All patients included in this study gave written informed consent to publish the data contained within this study.

\section{Competing interests}

The authors declare that they have no competing interests.

\section{Author details}

${ }^{1}$ Department of Radiodiagnosis, Faculty of Medicine, Menoufia University, Menoufia, Egypt. ${ }^{2}$ Department of Radiodiagnosis, Birket Elsaba Hospital, Menoufia, Egypt. ${ }^{3}$ Diagnostic and Intervention Medical Imaging Department, National Liver Institute, Menoufia University, Menoufia, Egypt.

Received: 13 February 2020 Accepted: 30 March 2020

Published online: 20 April 2020

\section{References}

1. Bartolozzi C, Cioni D, Donati FC et al (2001) Focal liver lesions: MR imagingpathologic correlation. European radiology 11(8):1374-1388

2. Corvino A, Sandomenico FS et al (2019) Morphological and dynamic evaluation of complex cystic focal liver lesions by contrast-enhanced ultrasound: current state of the art. J Ultrasound 11:1-9

3. Bamber J, Cosgrove D, Dietrich CF et al (2013) EFSUMB guidelines and recommendations on the clinical use of ultrasound elastography: basic principles and technology. Ultraschall Med 34:169-184

4. Honjo M, Moriyasu F, Sugimoto K et al (2014) Relationship between the liver tissue shear modulus and histopathologic findings analyzed by intraoperative shear wave elastography and digital microscopically assisted morphometry in patients with hepatocellular carcinoma. J Ultrasound Med. 33:61-71

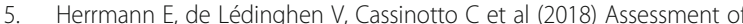
biopsy-proven liver fibrosis by two-dimensional shear wave elastography: an individual patient data-based meta-analysis. Hepatology 67(1):260-272

6. Ferraioli G, Tinelli C, Bello D et al (2012) Accuracy of real-time shear wave elastography for assessing liver fibrosis in chronic hepatitis C. Hepatology 56:2125-2133

7. Moustafa E, Makhlouf F et al (2017) Non-invasive assessment of liver fibrosis in patients with hepatitis C: shear wave elastography and color doppler velocity profile technique versus liver biopsy. Arab journal of gastroenterology 18(1):6-12

8. Guibal A, Boularan C, Bruce M et al (2013) Evaluation of shearwave elastography for the characterization of focal liver lesions on ultrasound. Eur Radiol 23(4):1138-1149
9. Park, H. S., Kim, et al (2015). Shear wave elastography of focal liver lesion: intra-observer reproducibility and elasticity characterization. Ultrasound Quarterly; 31(4): 262-271.

10. Ronot M, Renzo SD, Gregoli B et al (2015) Characterization of fortuitously discovered focal liver lesions: additional information provided by shearwave elastography. Eur Radiol 25(2):346-358

11. Frulio N, Laumonier $\mathrm{H}$, Carteret $\mathrm{T}$ et al (2013) Evaluation of liver tumors using acoustic radiation force impulse elastography and correlation with histologic data. J Ultrasound Med 32:121-130

12. Gallotti A, D'Onofrio M, Romanini $L$ et al (2012) Acoustic Radiation Force Impulse (ARFI) ultrasound imaging of solid focal liver lesions. Eur J Radiol $81: 451-455$

13. Heide R, Strobel D, Bernatik T et al (2010) Characterization offocal liver lesions (FLL) with acoustic radiation force impulse (ARFI) elastometry. Ultraschall Med 31:405-409

14. Cho SH, Lee JY, Han JK et al (2010) Acoustic radiation force impulse elastography for the evaluation of focal solid hepatic lesions: preliminary findings. Ultrasound Med Biol 36:202-208

15. Davies G, Koenen M (2011) Acoustic radiation force impulse elastography in distinguishing hepatic hemangiomata from metastases: preliminary observations. Br J Radiol 84:939-943

16. Virchenko, O. V., Bodnar, et al (2013). 1329 diagnostic accuracy of a new elastographic method (shear wave ${ }^{\mathrm{TM}}$ elastography imaging) in the noninvasive assessment of non-alcoholic steatosis in patients with type 2 diabetes. J Hepatol; 58: S536.

17. Masuzaki $\mathrm{R}$, Tateishi $\mathrm{R}$, Yoshida $\mathrm{H}$ et al (2007) Assessing liver tumor stiffness by transient elastography. Hepatology international 1(3):394-397

\section{Publisher's Note}

Springer Nature remains neutral with regard to jurisdictional claims in published maps and institutional affiliations.

\section{Submit your manuscript to a SpringerOpen ${ }^{\circ}$ journal and benefit from:}

- Convenient online submission

- Rigorous peer review

- Open access: articles freely available online

- High visibility within the field

Retaining the copyright to your article

Submit your next manuscript at $\boldsymbol{\nabla}$ springeropen.com 